\title{
Was European Integration Nice while It Lasted?
}

\author{
Miroslav N. Jovanović \\ Global Studies Institute, University of Geneva, Geneva, Switzerland
}

\begin{abstract}
The principal goal of integration in Europe has always been the safeguarding of peace through economic integration. The European Union (EU) has overseen splendid economic achievements. A sign of that great success has been the EU's continuous enlargement. The eurozone is the crown jewel in the process of European integration, but it is also its weakest component. The EU's most glorious attribute, the eurozone is now synonymous with harsh austerity measures, protests and no prospect of any remarkable growth in many countries for years to come. Obvious rifts between the EU's countries are shaking its foundations like never before. The EU passed through many crises (approximately one a decade), and it always exited stronger. This time may be different. The EU may weather the storm. It may, however, end up as a big and important group, but not a very happy family of nations. The first decade of the $21^{\text {st }}$ century was 'lost' for the EU, while the second decade may prove to be the epoch of its diminished global relevance. This is a pity as Europe has taken the reins in many global issues (e.g. environment). Compared with Europe, integration in Southeast Asia started from a very different point and at a different time. Nonetheless, the region provides certain context-specific lessons for the integration path. Given the circumstances in Southeast Asia, it is suggested that the region integrate but follow a light institutional model coupled with simple rules of origin to support efficient supply chains and production networks.
\end{abstract}

\section{JEL Classifications: F15, F53, F55}

Key Words: Germany, France, Eurozone, Russia, Break-up, Elite, Currency, Spontaneous, Bottom-up Integration, Southeast Asia

\footnotetext{
* Corresponding Author: Miroslav N. Jovanović; Global Studies Institute, University of Geneva, rue Daniel Colladon 2, 1204 Geneva, Switzerland, Tel: +41 22 9172493, E-mail: miroslav.jovanovic@unige.ch.

Acknowledgements: I owe a special debt of gratitude to Jong Eun Lee for the encouragement to write this article and Lisa Borgatti for her helpful comments. This article was edited by Charles Toby Pearce. The views expressed are my own and do not necessarily reflect the position of the organizations for which I work. I am solely responsible for all errors and mistakes.
} 


\section{Introduction}

What has been the story and legacy of European integration since the Second World War? European integration started amidst a unique and special post-Second World War environment. Germany was defeated and the presence of American troops assisted in Franco-German reconciliation, essentially on French terms. The principal political goal in Western Europe was to keep the peace and to make war between France and Germany materially impossible. The vehicle to reach that objective was economic integration. Hence, integration in Europe is a means to an end, not an end in itself. The European Union (EU) and its preceding institutional habitats have brought about tremendous positive achievements since the first inception of the European bloc in 1951. Apart from the protection of peace (the exception being the former Yugoslavia during the 1990s), other achievements in integration include successes in increased trade and wellbeing, consumer protection, enhanced competition, monetary affairs and agriculture, while also strengthening the rule of law and the spread of European democratic values. An obvious beacon of the bloc's attraction and success can be found in the continuous enlargements of the EU from six to 27 countries with 500 million rather well-off consumers.

The EU has managed to successfully weather a number of serious crises (roughly one a decade). It has usually exited stronger. The current crisis is shaking the foundations of the EU. The member countries can agree on almost nothing. ${ }^{1}$ The awarding to the EU of the Nobel Prize for peace in 2012 was one of the first pieces of positive news regarding the EU in years. It arrived at a time when the EU is facing its worst crisis of confidence, when the undeclared economic/monetary war is threatening social cohesion across the EU and when the popular support for the European project is waning because of crisis, debt, poverty, unemployment and little prospect for economic growth and prosperity. A more appropriate moment for the peace prize came in 2004 when the EU ushered the former communist countries firmly under its wing, rather than at the current juncture when the eurozone crisis impoverishes dozens of millions Europeans, the common currency divides the EU and when the euro is a cause of conflict and a source of violent protests (the EU was not considered for the Nobel Prize for economics). ${ }^{2}$

The core EU countries such as France and Germany are drifting apart (this is one of the most serious problems), while others such as Britain are disengaging from the EU project. Countries in the EU move at diverse speeds (eurozone and others), while some (Britain) are moving in a different direction to the rest of the EU. Certain countries - Belgium and Britain (Scotland) - are even on the road to internal break-up, while others have obvious separatist

\footnotetext{
${ }^{1}$ Various, serious and continuing rifts among the EU countries do not only concern crucial issues such as economic, monetary and financial policy, banking and institutions, but also energy, patent law, genetically modified organisms, enlargement, as well as relations with Russia, Kosovo, the military attack on Libya, etc.

${ }^{2}$ The Nobel Committee is in Norway, the country which repeatedly refuses to join the EU.
} 
movements: Spain (the Basque region and Catalonia), Italy (north of the country), France (Corsica), to mention just a few. Citizens have also demonstrated a relentless and long-term loss of interest in voting for members of the European Parliament, the EU's only directly elected institution.

There is also a gap in the perception of the European integration process and its future. The 17 eurozone countries (the EU 'first division') are struggling with the financial mess, while the other 10 EU countries (the EU 'second division') are kept on the sidelines. Rifts are also obvious within the eurozone countries: the thrifty north has a different vision from the prodigal south. Germany wants strict national fiscal discipline, while France is in favour of debt mutualisation. The EU-rim countries look at the EU as a source of bailout funds, while the EU core uses the EU as a tool to oversee the expenditure of the profligate countries.

The EU has come to embody not only the Swedish standard of living, German technical mastery and productivity, French social services and consumer rights, but also a ramshackle eurozone wrought with unsustainable debts, economic catastrophe in Greece, harsh austerity in Portugal and Spain, violent public protests, devastation in the agricultural production of Hungary and Romania, no prospect of growth in the long run, as well as a lack of enthusiasm for integration in the Czech Republic and the British airing their intentions of an exit.

What can one expect from the EU's future? The EU elite have convened an endless number of meetings in search of solutions to the huge gaps that divide the EU. What is the political currency that would keep the EU not only together, but also on a prosperous path? How best to avoid the observation by future historians that European integration was a nice project while it lasted?

The purpose of this article is to shed light on possible developments in European integration. It starts with an assessment of geopolitical issues such as relations between France and Germany, Britain and continental Europe, as well as ties between Germany and Russia. The next section is devoted to the 'dark masters' of the art of European integration. Future directions for the EU are the next subject matter, which is followed by a recap on the EU. Lessons for Southeast Asia are contained, and then finally the conclusion is in favour of integration as countries grow rich together, not at each other's expense.

\section{Geopolitics}

Geopolitics is a discipline which has as its principal subject a study of how a country's location in a given geographical space influences and determines the political events within its confines and in its surroundings. Geopolitics has three principal laws:

1. States make decisions based on the first and foremost in their national interests. 
2. All political states of affairs and events are transitory. Each established state of affairs may at times be changed fast and with 'ease'.

3. Long-term friendships, permanent unions, long-lasting understandings and eternal gratitude among countries in international relations do not exist. They have never existed in the long term. What exists and lasts is only the politics of national interest. However, these national interests may change rapidly and easily in accord with the given or changing situation.

One of the amazing things about geopolitics is how fast things can change (law No. 2). Europe has been a busy place in this regard. Take a look at the change in the political system and state frontiers. The political system in the countries of the former Eastern Bloc experienced a fast transition from 1989 onwards. The same has happened with the frontiers of several countries in Europe (Czechoslovakia, the Soviet Union, while in the former Yugoslavia there were both peaceful and bloody changes in the frontiers).

Fast-changing alliances may be exemplified by the case of Britain being with Hitler in Munich in 1938 (to the dismay of France and others) while three years later it was against him along with France and the communist Soviet Union. During the Second World War the Quisling-type Nazi collaboration systems were flourishing fast all around Europe. Elsewhere, Libya for a couple of decades was a pariah state. It was also bombarded and under sanctions. Then, in 2007, it was well accepted by the 'international community', even as a non-permanent member of the UN Security Council. This all happened under the same 'old' leadership in Libya (before it was bombed and ousted in 2011).

Let us consider several geopolitical issues which are relevant for the future of Europe and the EU. They refer to the Franco-German integration engine in the EU, Britain's relations with the European continent, as well as relations between Germany and Russia.

\section{A. Franco-German European Integration Engine}

There are various alliances within the EU. The principal Franco-German alliance (at times including the Low Countries) has been the EU integration engine. This alliance tends to be weakened by others, but their economic or political muscle is still not of comparable strength. Nonetheless, the Scandinavian countries harmonise their stance, Spain and Portugal often act together, while Britain allies with anyone that wants to slow down the process of European integration. Once in the EU, Britain has always been a strong supporter of its enlargement, in particular because it wanted to make the EU's composition 'looser'. The 2004 and 2007 eastern enlargements of the EU seriously shook its traditional operational arrangements. A possible eastern EU tier of a group of countries with similar histories and goals may add an important new factor that could contribute to the watering down of the leading Franco-German integration 
axis. This has the potential to slow down the entire integration process. It is also just what Britain wanted in the post-Second World War period, from outside the EU, and what it did from within it after entry in 1973. Basically, Britain wants to be at the heart of the EU decisionmaking process, but without being overcommitted, in order to leave generous room for its own manoeuvres. To put it bluntly: France and Germany make (or made) unhedged bets on Europe, while Britain has always been hedging them.

The Franco-German friendship and cooperation remains strong even though it has suffered upsets, some of which were quite serious. Examples include German re-unification in 1990, when France had concerns about the might of a neighbour with 82 million inhabitants; ${ }^{3}$ French frustration at Germany's rushed recognition of Croatia in 1991; the French row regarding the German-inspired Stability Pact for the single currency; German objections to the French nuclear tests in the Pacific in 1995; German hostility to the French president of the European Central Bank; German worries about French hesitations concerning the eastern enlargement; and the rift regarding the military intervention in Libya in 2011 (France recognised the opposition Libyan National Council without consulting its EU partners and then led the military charge). There have also been concerns about nuclear power plants before and especially after the Fukushima disaster in Japan, concerns about particular relations with the United States (US) and Russia, and differences on how to tackle the eurozone crises. Nonetheless, cooperation between France and Germany always emerged safe and sound after these rifts. This relationship between France and Germany is not automatic. It is/was built, maintained and repaired as a political choice and through the will to build an effective and prosperous EU, as well as a safe Europe. These two countries have fully realised that it may be better and safer to be united and cooperate than to stand against each other.

The election of Françoise Hollande to run France (2012 2017) may have paved the way for certain problems. While the German-inspired fiscal pact is based on a tough austerity doctrine, Hollande was elected on the growth and employment ticket, which is rather easy on the public budget. This may set France on a collision course with Germany. Can the workable interestbased alliance turn into an unworkable French-German argument? What type of recalibration of French-German relations is in the pipeline?

Even though Germany has already achieved economic dominance in Europe, a strong Franco-German relationship still exists. This was exemplified by a joint action to escape the eurozone's fiscal rules in 2003 (the two countries do not always work for the benefit of the entire EU). Even though this special relationship between the two countries still exists, it is being modified. The recognition of the break-up of Czechoslovakia, Yugoslavia and later Serbia may not necessarily be in step with French national interests, but it is strongly in the interests of Germany as the last traces of the French-sponsored 1919 Versailles peace treaty

\footnotetext{
3 Germany has always been a sticking point in Europe. When it was 'big' and strong, neighbours were encircling it with coalitions. When it was shattered, 'small' neighbours were making sure that it remained so and did not unite. In any case, Germany has seldom been let alone.
} 
(concerning European geographical partition) were erased through these events.

The (temporary) emergence of the London-Madrid-Rome partnership in 2003 (on the issue of the war in Iraq) may merely reposition, rather than replace the Paris-Berlin alliance. The Franco-German partnership is still necessary for the stability of Europe; but it is not sufficient. Germany is now locked in the EU for some time to come, but the question still remains as to how it will use its clout in future EU affairs. Would this be 'European Germany', or 'German Europe'?

As a rule (so far), when France and Germany and perhaps another large EU country reach agreement on an important issue during the very last minutes of negotiations and horse-trading, then they draw others into the deal. It remains to be seen how this type of EU integration engine would operate in the future.

After 'crawling', being the paymaster for many European projects and being told what to do since 1945, Germany is becoming a 'normal country': a country which loudly and proudly expresses and pursues its national interests and priorities in an unprecedented way, or at least in a manner not seen since the end of the Second World War. The aftermath of the Cold War turned out to be a glorious time in the history of Germany. This does not mean that German national interests are always in step with the interests of other EU countries. Germany may, for instance, allow an increase in lending from the eurozone rescue fund if those foundering countries accept German social and economic order. Germany is also losing patience regarding the flouting of mutual trust by EU partner countries. Together with France, Germany is not permitting the entry of Bulgaria and Romania into the Schengen document-free travel deal until these two countries bring their levels of crime and corruption under control. Germany and France and others also have little confidence that Bulgaria and Romania can police the Schengen borders properly.

A proper debate about EU membership has never taken place in Germany. After the Second World War and the Treaty of Rome (1957), it was taken or prescribed that what was good for the EU was also good for Germany. The real costs and benefits of being in the EU were never openly debated in Germany. The latest generation of German politicians believe that the country has already paid its historical dues and they have an open mind about the costs and benefits of the country's participation in EU projects.

When Germany is assertive, it is accused of building the Fourth Reich. If it is hesitant (like before and during the military charge against Libya in 2011), it is labelled by many as a useless country. However, Germany is doing what all normal counties do: it takes care of its own national interests first and foremost.

The new generation of politicians in Germany now pursues the national interest without the heavy burden of the Second World War and post-Nazi Germany. There is nothing wrong about that. Britain and France have always forcefully pushed their national interests in the EU. The problem is that in difficult times some politicians in the EU may perceive the EU as a zero-sum gain institution for their own country. This may endanger the Single European Market, which 
could be fragmenting. If the perception of the EU falls into disrepair, everyone will be a loser. Nonetheless, the new generation of German chancellors that have emerged since the time of Gerhard Schröder (in office 1998 2005) do not look at European integration as an idealistic project, but rather view it in a utilitarian and pragmatic manner.

Germany is a crucial power factor at the heart of the EU. Economic crises (especially since 2010) have exposed and wrecked the myth of EU-level parity between France and Germany. However, there is a key policy dilemma facing Germany as a potentially 'expanding regional power' over the coming decades. It deals with demographical trends. Given the low birth rate, if Germany does not accept approximately 350000 immigrants per year, it could shrink from 82 to 60 million people by 2050 (Messerlin, 2001, p. 255). Is this a symptom of a shrinking hegemony?

\section{B. Britain and Europe}

Ever since the Roman legions departed from the shores of southern England in $410 \mathrm{AD}$ (after 367 years of occupation) Britain has always been somewhat semi-detached from, and quite suspicious of, continental Europe. In the same vein, Britain has always seen the EU as a Franco-German 'plot'. As such, it accepted the EU as something inevitable, rather than something to be enthusiastic about. Even though there were occasional attempts to include the British in the 'inner EU core', the Franco-German pairing never bloomed into a ménage à trois with the British. The problem is not only that even after some four decades in the EU Britain cannot clearly decide whether it wants to be a full participant in the EU venture, but also that France and Germany were for a long time too close to allow a third country to come between them. In any case, Britain has praised the benefits that come from not participating in prime EU projects such as the eurozone and the Schengen deal. Those benefits became obvious in 2011 when these two projects encountered serious setbacks.

Britain's overseas possessions were either very far away (North America, Australia, India, Kenya,...) or small (Gibraltar), or both. If things went wrong (American Revolution, Ghandi's rebellion,...) Britain could pack and go home. The point is that its island-type territorial integrity was not in danger. Countries on the European continent such as France, Germany, Austria-Hungary, Russia, Denmark or Turkey did not have such a choice. The geopolitical choice of all these countries could have been best described in the succinct words of the German born and raised Catherine the Great (1729 1796): 'I have no way to defend my borders except to extend them.' The extension of borders was linked to encounters with hostile people; frontiers were overstretched and this was one of the reasons why all of them failed, from the Roman Empire to Napoleon's conquests, Hitler and the Soviet Union.

Being an island, Britain was not threatened. The only thing which could threaten Britain would be a united European continent. Every time Europe was united under a single hand, 
that hand had an eye on Britain. This is one of the very rare things that makes Britain scared. As long as Britain was outside of the European project, it could not exert influence over integration events. Therefore, the British EU entry was not to promote integration, but rather to hamstring the process. The British vision of the EU was to be an apolitical glorified version of the European free trade area (a European Commonwealth). Charles de Gaulle grasped this well, hence he vetoed the British EU entry twice.

The integration marriage between Britain and the EU was not a happy one. Britain was rather late at the altar and it has too many opt-outs from the integration projects. Britain may consider withdrawing from the Common Fisheries Policy. As such, there are doubts about Britain's commitment to the EU. Hence, Britain cannot play a strong (leading) role in the EU, which it could otherwise do. Instead of being located next to the EU driver's seat, Britain may easily be in the EU's dog boot. Many would even argue that Britain became in many dimensions the EU's poison pill.

Earlier, and to put it in very simple terms, when France tried to create and hold an empire, Britain plotted against the venture, and together with Russia, Austria, and Prussia, contributed to Napoleon's defeat in 1815. Before that, Britain defeated Spain on the high seas in 1805 . Britain was also between Russia and the Middle East (in favour of Turkey). In 1854 1855, Britain fought the Crimean War against Russia. However, in 1915 1916, Britain along with France, Australia and New Zealand unsuccessfully attempted the invasion of Turkey (Dardanelles Strait - Gallipoli) in order to relieve the Turkish pressure on Russian forces in the Caucasus and to control the straits. When Germany sought supremacy in the two World Wars, Britain joined France and Russia against Germany. But between those two wars, in 1938 (the Munich Agreement), Britain was with Nazi Germany and let it occupy the Sudetenland and control the rest of Czechoslovakia to the dismay of France and Russia. ${ }^{4}$ Then in 2004 2005, Britain was between Turkey and a number of EU states that had serious doubts about Turkish credentials for EU eligibility.

Creating, producing, operating and storing nuclear weapons is a complicated, expensive and a very long-term venture. There is always an alternative investment for such enormous amounts of taxpayers' money. The publicly stated reason for having them in Britain was the nuclear threat from the Soviet Union/Russia and various rogue states. However, the real and the biggest reason for having such weapons in Britain has always been concealed. It is that Britain can never permit France to be the only nuclear power in (Western) Europe.

The British voted in 1975 to remain in the European Economic Community (the EU's name at that time). The presumption, even promise, was that the organisation would be a common market. As the organisation expanded its coverage over various administrative and policy areas, some in Britain have taken the EU to be a kind of 'soft occupying force'. Is the 1975

\footnotetext{
${ }^{4}$ The British (deeply German rooted) royal family changed its official name to the House of Windsor from its original SaxeCoburga and Gotha because of anti-German sentiments in 1917. The same happened with the 'blue blood' Battenberg family's name which was converted into Mountbatten.
} 
mandate eternal? The City of London is also concerned about the expanding level of financial regulation from Brussels. This continuously undermines the financial flexibility that was one of the prime attractions that London has been able to offer to the financial industry. If the EU, especially the eurozone, continues its possible path towards a fiscal and banking union in which all policies are subordinated to the euro, such developments would change the nature of the EU beyond recognition. Decision-making would be altered too. There are therefore strong political voices that are asking for a national referendum about the continued British membership of the EU. The British Chamber of Commerce called on the Government to halt the imposition of meddlesome new regulatory burdens from Brussels, especially regarding the labour market. One of the British strengths was the flexibility of the domestic labour market. Rules from Brussels may undermine this, especially during times of slow growth.

The 9 December 2011 EU summit was tinkering with the salvage of the troubled eurozone. During the summit Britain vetoed the new EU treaty that would allow for EU or eurozone control and approval of national taxing and spending (budgets) based on the German template. The deal was supposed to salvage the troubled eurozone. 'For his fellow European leaders, this was a moment of truth. After years of swerving round the core question - are you truly committed to Europe? - Britain was finally forced to give an answer. And its answer was No. Even Margaret Thatcher had avoided doing that, threatening but never using her veto. ${ }^{5}$ Britain not only entered the EU slow lane, but also took a road in another direction. De Gaulle anticipated this when he vetoed the British approaches to join the group. An illusion that Britain and the eurozone countries could joyfully live together under the EU roof evaporated. Mervyn King, Governor of the Bank of England, 'identified Europe as the biggest threat to the UK's still-faltering recovery from the 2008 2009 recession. ${ }^{6}$ If Britain leaves the EU, it would remove a strong flavour of liberalism that Britain (nominally) stands for. The EU may potentially become in a sense more narrow-minded.

Lasting friendship, durable alliances, permanent enemies, lifelong understanding and enduring gratitude in international relations simply do not exist. They have never existed in the long term. What exists and lasts is only the politics of national self-interest, as geopolitical law No. 3 dictates. But the object of this national interest can change easily and fall rather quickly into disfavour according to the interest of the given moment. Opponents of such a geopolitical view would argue that all the mentioned relations exist, but they may be slightly altered because of 'temporary emphasis'. Old and persisting geopolitical rules ought to be looked at through the lenses of new needs.

\footnotetext{
5 J. Freeland, 'The two-speed Europe is here, with UK alone in the slow lane', The Guardian, 9 December 2011.

${ }^{6}$ I. Traynor and L. Elliott, 'Greece is being forced out of eurozone, Venizelos claims', The Guardian, 15 February 2012.

It is hard to join the EU, but it is also tough to leave it. Departure would be a hard blow to the European integration idea. Spain rumours that it would be quite tough on Scotland if it leaves Britain and if it wants to join the EU. Spain, of course, has several regions of her own that may follow the possible intentions of Scotland. For the record, the only two entities that left the EU were Algeria in 1962 (it was regarded as a part of France before the departure) and Greenland in 1985.
} 


\section{Germany and Russia}

Ever since the unification of Germany in 1871 the most striking feature of European history has been the struggle by various countries to constrain overall German might. The 'German problem' following its unification has always been the same: the unified country's strength. Even though Germany is powerful, it is not omnipotent. Germany needs a partner country in Europe. Its coalition partner in the post-Second World War period of occupation was France, both by pressure and by choice. In modern times, however, the eurozone crises have stepped up the shift of power from Brussels to Berlin:

One top EU official scoffed that - "France needs Germany to disguise how weak it is. Germany needs France to disguise how strong it is." Now even the disguises have dropped. ${ }^{8}$

In the past, Germany had an alternative: it was Russia with which it shared both a rich history of alliances ${ }^{9}$ and bitter conflicts. Monogamy is fine in marriage, but not in politics or business.

After the reunification in 1990, Germany slowly started to speak, act and think about itself and its own national interests first, just as all 'normal countries' do. An interesting thing is that during the election campaigns in the resurgent and more independent Germany, ${ }^{10}$ politicians since the mid-2000s have increasingly debated German issues in the exclusive manner, not the EU ones. It was traditionally thought that what is good for the EU had to be good for Germany too. Still, this type of placing national interests first, new for Germany, is a standard occurrence in countries such as Britain or France. Hence, this German 'nationalism' is something normal in Europe and elsewhere. It should not be scary. At least not until Germany is tied to the EU.

This re-emergence started to become evident and flourish during the time that Gerhard Schröder was German Chancellor (1998 2005). It came about during the EU's eastern enlargement (2004), around the same time it became obvious that Germany was gaining the pivotal position in the EU. Without Germany (and France, in that order now) nothing important happens in the EU. When the two countries disagree, the problem is referred to as 'paralysis' within the EU. When they agree, other countries object because of the intolerable demands made by the two countries. ${ }^{11}$ The pre-reunification fears of France and the de Gaullists are coming true. The EU was created at a time when Germany was down (an abnormal country) with a heavy Second World War burden on its shoulders and when France could use the EU to project its own geopolitical power and ambitions. This was rather 'simple' when Germany was

\footnotetext{
${ }^{8}$ G. Rachman, 'Welcome to Berlin, the new capital of Europe', Financial Times, 23 October 2012.

${ }^{9}$ Catherine the Great (1729-96), League of the Three Emperors (1873-78), Reinsurance Treaty (1887), Treaty of Rapallo (1922) and Molotov-Ribbentrop Pact (1939). 'Otto von Bismarck declared in 1863 that the secret to politics was "a good treaty with Russia"' (B. Benoit and R. Milne, 'How disputes are exposing the limits to German 'Ostpolitik', Financial Times, 15 May 2007).

${ }^{10}$ Major states and nations have strong regenerative capacities. Examples include Germany, Japan, Russia and China.

${ }^{11}$ Franco Frattini, the Italian foreign minister, angrily stated that 'Pre-cooked decisions put on the table to be taken or left by others is not acceptable for other countries like Italy and other big players' (G. Dinmore, 'Italy slams Paris and Berlin for pre-cooked deals', Financial Times, 4 November 2010).
} 
occupied and later on when American troops remained. However, this situation did not last. Following the fall of the Berlin wall, the 'former British Prime Minister Margaret Thatcher and former French President Francois Mitterrand were anything but pleased about the speed with which West and East Germany proceeded with reunification in the early 1990s. Thatcher even asked then-Soviet leader Mikhail Gorbachev to put a stop to the reunification. ${ }^{12}$ The Soviet/ Russian leader did not yield to this request, which worked in the Germans' (Russo-German) favour. It is interesting and amazing just how fast and easily France and Britain slipped back towards $19^{\text {th }}$ century policies in this scenario (geopolitical laws No. 2 and 3, respectively).

The French diplomatic solution to the new situation with the reunified Germany was as creative as ever. France's relations and involvement in Europe have almost always been disastrous in military terms, but never in diplomatic ones. In 'exchange' for reunification, France ensured Germany was 'locked' into the European project through the Maastricht Treaty and the monetary union, at least for the foreseeable future. Without the reunification of Germany, the eurozone may not have come about, at least not that fast. By entering into a monetary union with Germany, France 'passed on' an important part of its domestic economic policy to Germany in order to 'lock' Germany firmly into the European project.

France has come up with a number of original plans to control and/or be in partnership with Germany since the end of the Second World War. What would happen if the 'monetary cage' breaks up and Germany goes on its own and seeks partners elsewhere (possibly Russia) in the longer term? What would happen to the French economy if the 'monetary cage' holds and French economic policy is constrained by German economic policy?

While France and Germany need each other to lead Europe, they may not be able to do so on their own. Each of them needs a partner for this important job. If the economies of these two countries diverge in the future, would Germany wish to keep France as a partner in the longerterm future? This decision will be made in Berlin. Some may argue that Paris is no longer an equal partner of Berlin. Nevertheless, France has a millennium-long history of diplomacy and political stratagems designed to handle such tough situations.

Germany and Russia fought bitterly during the Second World War. However, better ties between these two countries would only return relations between them to the state in which they existed for a long period of time. This period began with the German-born and educated Catherine the Great (1729 1796), who ruled over Russia (1762 1796) with an efficient Pomeranian (Prussian) hand and made it a modern, organised and prosperous country.

Germany is again turning into Russia's entryway to the West. Over recent decades, German chancellors have continuously held rather cordial and friendly longer-term relations with their counterparts in Moscow. Helmut Kohl was on good terms with Mikhail Gorbachev and Boris Yeltsin, Gerhard Schröder was visibly on very friendly, comfortable and informal terms with Vladimir Putin, while after certain apprehension Angela Merkel now gets on quite well with

\footnotetext{
${ }^{12}$ Stratfor, 'EU: consequences of the Greece intervention', 2 April 2010.
} 
Dmitry Medvedev and Putin, especially after signing a set of lucrative trade deals in $2010 .{ }^{13}$ These relations and the partnership itself are based on a growing common interest in trade and investment that go beyond energy, combating terrorism and the provision of supplies for German troops in Afghanistan through Russia, not to mention certain common cultural heritage. Good relations between these two countries are valuable to the both of them. Germany would gain secure access to energy, resources and the Russian market, while Russia would get secure revenue and access to technologies that could transform it away from being the primary-products exporter. In particular:

Germany has a shrinking population and needs a source of labor — preferably a source that doesn't actually want to move to Germany. Russia's Soviet-era economy continues to de-industrialize, and while that has a plethora of negative impacts, there is one often-overlooked positive: Russia now has more labor than it can effectively metabolize in its economy given its capital structure. Germany doesn't want more immigrants but needs access to labor. Russia wants factories in Russia to employ its surplus work force, and it wants technology. The logic of the German-Russian economic relationship is more obvious than the German-Greek or German-Spanish relationship. As for France, it can participate or not (and incidentally, the French are joining a number of ongoing German-Russian projects). ${ }^{15}$

Along the lines of re-establishment of powerful ties between Germany and Russia, the Russian Defence Ministry made an important deal in 2011 with Rheinmetall, a private German defence company, to construct and equip a combat training centre for the Russian military at Mulino, near Nizhny Novgorod. Rheinmetall is the top European supplier of defence and security technology for ground forces, which also sold Russia armour plating at around the same time. ${ }^{16}$ This centre would be for brigade-size military units (thousands of soldiers). It would upgrade their ability to shape and simulate the tactical combat operations of Russian ground forces.

France is also strongly involved in the upgrading of Russian offensive forces and the transfer of military technology to Russia. According to a deal agreed in 2010 and 2011, France would build for Russia at least two Mistral-class carriers of helicopters and amphibious assault

\footnotetext{
${ }^{13}$ An interesting detail regarding these special relations between Russia and Germany is related to the visit of the Russian Prime Minister Putin to the European Commission in February 2011. 'The massive Russian delegation hired 30 limousines from the commission car pool, specifying that they only wanted German brands such as Mercedes, Audi and - for junior officials - Volkswagens' (A. Rettman, 'Barroso-Putin tete-a-tete: three victims named', EUobserver, 25 February 2011).

${ }^{14}$ Germany and Russia (China too) do not attach as many political strings and conditions in relations with other countries as do the EU or the US. As such, they enjoy the rather comfortable liberty of being able to settle various issues in a pragmatic and cosy manner.

${ }^{15}$ Stratfor, 'Germany after the EU and the Russian scenario', 25 May 2010.

${ }^{16}$ Stratfor, 'The significance of Russia's deal with Germany's Rheinmetall', 16 February 2011; Stratfor, 'The European perspective of Biden's Russian visit', 9 March 2011.

Military cooperation is nothing new in German-Russian relations. For instance, the Treaty of Versailles (1919) prohibited Germany from operating an air force or tanks. Nevertheless, between the two World Wars the military cooperation between Germany and the Soviet Union flourished until the early 1930s when ideological differences between the two countries became unmanageable. Kampffliegerschule Lipezk (the Lipetsk fighter-pilot school) was a secret training school for Luftwaffe pilots in Lipetsk (south of Moscow). There was also a secret school for tank commanders (Panzerschule Kama) in Kazan.
} 
vehicles (each has the storage capacity for 60 armoured vehicles). It would also transfer the necessary technology to Russia which could then build such ships on its own in the St. Petersburg ship yards. As part of the deal, the French and Russian shipbuilders agreed to form a consortium to build military and civilian vessels too. Aside from the military sector, France would also like to expand its relations with Russia in the fields of energy and space. Those are areas where Germany is rather weak, hence there is no overlap of interests and penetration into Russia is easier. ${ }^{17}$ Germany, and increasingly France, are looking to Russia more and more as a lucrative business partner in all spheres. The problem is to square those economic and political interests with obligations in NATO, especially at the easternmost and westernmost parts of that alliance. The NATO countries are becoming rather strange bedfellows.

Rare earth elements are used in the manufacturing of sophisticated technological products. China has had almost a global monopoly on the supply of these raw materials since the 1990s. Demand for these rare earths has been rising and China decided to limit their exports in order to first supply their domestic producers. This created trade troubles with the EU and led to the WTO intervention in 2011. However, China continued to control and restrict its exports of these elements. Producers of high-technology goods started looking elsewhere for potential supplies. Germany was interested in the alternative suppliers for its own high-technology industry. In light of this, Russia, for instance, agreed in 2011 to allow Germany access to its deposits of rare earth elements.

The re-establishment of cosy and robust ties between Russia and Germany may not sit well with other EU countries such as Poland and Lithuania. The only land border that these two countries have with Russia is with the Kaliningrad enclave. The US is not happy about strong relations between Germany and Russia. In fact, the US may even prefer to see certain tensions, rather than rapprochement between the two countries. ${ }^{19}$ Regardless, Germany may be looking for coalition partners that may add to its own welfare, rather than draw on it (as are many EU countries). Sacrifices can be made in the name of Germany, although this can no longer be done, in the name of the EU. France and others may think and do the same, too.

Energy is in the heart of EU-Russia relations. The European Commission confirmed Russia's reliability as a supplier of energy. ${ }^{20}$ Russia confirmed from the highest state level that it has always had a long-term policy of being a reliable supplier of energy. The construction of the Nord Stream gas pipeline is a sign of long-term close cooperation between Germany and Russia no matter who is in power in Berlin and Moscow, now or in the future. The company was established in 2005. Germany needs this reliable source of energy as environmental

\footnotetext{
${ }^{17}$ In the quest for military modernisation, Russia 'attracted a number of Houston-based NASA employees who were laid off recently' (Stratfor, 'Russia and France: new levels of cooperation', 21 June 2011).

${ }^{18}$ Bridges Weekly, 'Tensions build between EU, China over rare earths in aftermath of raw materials decision', 20 July 2011.

${ }^{19}$ The US interests and policy is to never let any country develop anywhere enough strength to be able to control a continent.

${ }^{20}$ Commission of the European Communities, Communication from the Commission to the Council: 'Review of EU-Russia Relations', Brussels, 5 November 2008, COM(2008) 740, p. 3.
} 
concerns avoiding building nuclear power plants. After the Fukushima nuclear disaster, Germany decided on 30 May 2011 to gradually phase out all of its 17 nuclear power plants by 2022. The next day, Philipp Roesler, the German Economy Minister, visited Russia to discuss energy issues with Russian officials (incidentally, the Minister did not first go to Brussels or anywhere else).

Germany and Russia constructed the Nord Stream gas pipeline on the Baltic Sea floor. Its cost is at least four times that of an overland route. Some newer NATO members from the east may even see Germany as the Russian 'fifth column' in the EU. Nonetheless, the conspicuous messages from these two countries to the new eastern EU and NATO states from the Baltic region (especially to Poland) are that:

- Germany and Russia do not regard these countries as reliable overland transit countries,

- Germany and Russia are ready and willing to incur enormous infrastructure costs to bypass them. They put their big and long-term money where their mouths are. As such, this is a blow to energy unity in the EU.

Political statements, declarations and intentions about common EU energy policy and solidarity are one thing. The actual situation in the energy field is another. Cooperation is rather weak, while a certain silent spirit of rivalry exists between the EU countries. Every key EU energy project is divisive: some countries will show support, while others will not. Major EU countries prefer bilateral gas deals with Russia. Such bilateral developments are exactly what the existence of the EU was supposed to prevent. Germany and France perceive Russia not as a current security threat, but rather as a partner in energy and commerce. The two EU countries have grown tired of American adventures such as Iraq and Afghanistan, which have high costs but dubious results and benefits. France, therefore, wants to be as close to the German-Russian duo as possible.

Franco-German reconciliation and their current partnership stated after the Second World War. It was strongly assisted by the American, British and French occupation of the western part of Germany. The Franco-German partnership resulted in strong cooperation in many domains that worked to the benefit of Europe. The renewed German-Russian partnership and cooperation is based on the pure and genuine commercial and national interests of the two countries. There is no external pressure, such as occupation, for the establishment and fostering of such relations. If certain external pressure appears in the future it may harbour the intention of damaging German-Russian ties, and this is exactly what is in the long-term interests of the US: never to permit strong liaisons between Russia on the one side, and Germany or China on the other. ${ }^{21}$ So, how to damage German-Russian relations? Well, one way is to stimulate the expansion of Islam in Germany.

\footnotetext{
${ }^{21}$ Stratfor, 'Geopolitics of the United States, Part 1', 25 August 2011.
} 


\section{III. 'Dark Masters' of the Art of European Integration}

At first the European elite led the integration process predominately through an economic doctrine. Political concerns started to feature higher on the agenda from the mid-1980s, while constitutional matters were somehow neglected. This is why the national elites and governments treated Europeans to a large extent as consumers, rather than as citizens and voters. There was a price to pay for that vision and behaviour: initial backlash in referendums.

The European elite are becoming increasingly afraid to verify democracy through referenda. Decisions are taken and implemented in the exclusive and closed elite-led political process. If things go wrong, the elite which rule over our lives blame Brussels. With this in mind, Ken Livingston's (1987) book has a revealing title: If Voting Changed Anything, They Would Abolish It. Voting may not be the actual means in which the EU integration business is achieved in reality. Whenever policymakers consult the people on EU matters through the voting process, and when they do not get the pre-set decision, they force the people to vote again and again (Denmark and Ireland) until they approve the decision that has already been taken. This type of management of EU affairs created a kind of democratic deficit which evolved into a democratic crisis.

The Greek government announced on 2 November 2011 that it would hold a referendum as soon as possible on the bailout programme in order to get a clear mandate from the people to stay in the eurozone. That announcement created 'shock, panic and anger' around the world, but especially in France and Germany. The French Prime Minister, Fillon, said that 'France regretted the unilateral decision by Greece to hold a referendum'. ${ }^{22}$ The fear was that a negative reply to the bailout programme would trigger sovereign default, as well as bank failures that could wreck the eurozone. The Greek Government withdrew the decision in a matter of days, under foreign 'peer pressure' because of real fears that the response from the Greek people would be a 'no'. At the same time Italy was passing through a deep financial crisis. The question and worry was if the Berlusconi government was able and willing to carry out unpopular expenditure-cutting reforms. The appointed (not elected) EU President, van Rompuy, said in Florence, 'This country needs reforms, not elections'. ${ }^{23}$ Once again, referendums may not be the way to conduct the EU's business. Is this a post-democratic EU?

A referendum may not always be the most appropriate way to have people speak on certain issues. In complicated matters such as treaty texts, voting may be skewed. If voters are not informed properly by politicians and the media, then sectoral interests may prevail. For instance, farmers may be against reductions in subsidies, housewives may be in favour of increases in benefits for part-time work, while domestic plumbers may be against an increase

\footnotetext{
${ }^{22}$ Bulletin Quotodien Europe, 'News of Greek referendum stuns the world', 3 November 2011, p .4.

${ }^{23}$ R. Winnett, 'Eurozone split would destroy single market', The Telegraph, 11 November 2011.
} 
in work permits for foreign plumbers. These sectoral interests may distort the general interests that a treaty aims to promote. In certain cases, and if key national sovereignty issues are not compromised, national parliaments may be more appropriate places for decision making. In addition, national referendums in France normally turn into voting on the popularity of the current government, no matter if the question asked on the voting slip relates only to France or the EU.

The disillusion problem regarding European integration is perhaps less to do with the fact that the European elite decides the shape, extent, speed and direction of European integration. The problem lies much more in the fact that the arrogant elite disdains voters and does not try hard enough to explain and convince the electorate that European integration is for the good of all in the long term. There is an obvious distrust from a significant part of the electorate towards the distant, alienated, un-auditable and unaccountable patrician elite that imposes European rules. If this elite occasionally holds a referendum on certain crucial national interests regarding European integration, it may easily run as many referendums on the same issue as necessary for it to achieve the required outcome. This gives an illusion of democracy, but in fact the decision has already been made behind closed doors and away from the public.

Big EU countries may not be requested or forced to re-run a referendum. Normally, when they say 'no', it means no. Still, the European elite are in a quandary when the answer is no. This situation is similar to one in which a young man asks a girl to go see a film with him, and when she says 'no', he asks himself whether she said 'no' to him or to the film.

What is the point of holding referendums when the elite ('dark masters' of the EU's integration art) ignore the results? The EU elite is like a pushy suitor who cannot take 'no' for an answer. If you cannot take 'no' for an answer, why do you ask a question? Respect for a national decision is formally given; but not too much, especially if a country is small. So the experience teaches us the following: Respect for the national democratic decision is such that those who do not like such decisions try to overturn them in the name of democracy. In a functioning democracy, an effective political leadership (elite) has the possibility, even obligation, to tell the voters that they were wrong. However, the EU elite has failed to communicate well, in an understandable and acceptable way, with the citizens and voters.

The European and national elites have to work very hard indeed to win the hearts, minds and confidence of citizens for ongoing (eurozone) and further projects in European integration. A vague promise that the future economic benefits will outweigh the costs is no longer as safe a bet as it once was.

The elite still thinks that the key to the European integration success is the smart drafting of documents (behind closed doors) and appropriate horse-trading (ditto). This has been a longstanding formula for success. However, it was based on effective leadership, which has been in rather short supply of late. There is a lack of great new ideas and inspirational developments such as the single market, the common currency, or perhaps eastern enlargement, that are powerful enough to inspire change. In spite of talks on the new common energy policy in the 
EU, big countries (Germany, Italy) prefer bilateral energy deals with Russia. One will see in the not-too-distant future just how well the new EU green and smart economy idea for 2011 2020 will fare.

\section{Where does the European Union Go from Here?}

The EU is neither an intergovernmental organisation, nor a federation. It is neither a federal nor a confederal institution in which member countries pool their sovereignty in certain matters. It is as unique and difficult to define as a political entity using the standard textbook classification tools and models. The EU is a special product of political creativity and necessity following unique, perhaps unrepeatable circumstances after the Second World War. Like in physics and economics, initial conditions matter in politics too.

Voluntary integration in Europe has been a marvellous political and economic success, well beyond the initial dreams of its creators who in 1957 had the collective experience of two devastating wars. The Treaty of Rome created tools for partnership and cooperation in Europe after centuries of armed rivalries and ideologies that threatened the entire civilisation. What came was stability and prosperity to be admired and sold on a large scale. The path was, of course, not a calm-flowing river.

The political currency for integration in the EU was the protection of peace and democracy for over half a century. These goals were achieved and for a long time have been taken for granted. What is the integration currency of the future, especially during the EU's ongoing mid-life crisis? Can a new sense of EU purpose be found in the spread of social prosperity and the 'green economy'? While the Single European Market was silently digested (save for services), the eurozone project has encountered trouble. Caring for the European social model (everyone has to have a secure, decent standard of living) may be a new objective. Still, this has to be debated in more depth. This social model is regarded as tantamount to a very financially dear system of doing things. It is often based on a mountain of unsustainable public debt. If the spread of peace and democracy in Europe involves EU enlargement, then the free mobility of the so-called 'Polish plumbers' may undermine the stable European social model in the 'old' EU countries.

The EU is at an important turning point. In the economic field the EU cannot create new jobs and reduce unemployment. The eurozone was the Union's major undertaking during the 1990s. Since then, some of the EU member countries have been trying to stick to the tough macroeconomic criteria prescribed by the Maastricht Treaty and the Stability and Growth Pact, which were supposed to prevent governments from overborrowing. At the same time, the EU enlarged eastwards. The goodwill of all member countries regarding all EU policies and actions cannot be taken for granted any more. The EU may face a bumpy road in the foreseeable 
future.

The eurozone, the biggest integration achievement, is also the weakest link. The ill designed, badly disciplined and overstretched monetary integration group is in danger of cracking apart. If this happens (many monetary unions in Europe fell apart in the past), this may damage integration and bring long-lasting divisions that often deeply damaged Europe (Jovanović, 2012).

The EU perceives itself as a global force for good and prosperity. Many outside the EU see it in the same way and wish to join or to have optimal relations with it. Why on earth is there such ambivalence or even pessimism within the EU? ${ }^{24}$ It is because there is no full understanding of how things are done in the bloc? If a big programme fails, the EU elite cut it into pieces and push it through, bit by bit, until a point of no return is reached. This perception of 'black box' decision-making without explanations of why there is a daily stream of laws which are not clear to the man in the street is reinforced by the un-auditable accounts of the EU's expenditure. ${ }^{26}$

Eurosceptics fear that a stronger EU would mean a return to multinational structures in which the European Commission in Brussels would replace the Hapsburg or the Bourbon courts. They regard the unelected 'rulers' from Brussels with high academic titles as reincarnated untouchable, uncontrollable and un-auditable former princes or archdukes. ${ }^{27}$ They compare the streets of Brussels to the streets of the late Habsburg Vienna: both are crowded with well-dressed, highly paid and corrupt officials (at least some of them). ${ }^{28}$

If the declared goal is that the EU does not want to cause losses of national sovereignty, then it is not clear what the EU is currently trying to achieve. The EU created a customs union that is broad and is getting broader. It created a single currency within the eurozone which is not as extensive as the customs union and is plagued with problems. The next integration steps may involve taxation and energy. Once those are gone from the national level, so is sovereignty. If the ability to levy taxes, mint money and make war is taken away from states, they have lost their full sovereignty.

The EU has had a tremendous age of achievements since 1990: the Single European Market,

\footnotetext{
${ }^{24}$ 'A survey of nearly 25,000 people from across 22 countries for the BBC World Service reveals for the first time sharply declining confidence in Europe as a force for good in the world' (O. Wright, 'How the world fell out of love with Europe', The Independent, 11 May 2012). The decline is linked with the grave eurozone crisis.

${ }^{25}$ The EU becomes overregulated. Regulation covers areas that range from energy efficiency over digital tachographs in lorries, obesity and up to the length of ladders.

${ }^{26}$ The EU Court of Auditors has not given a single positive approval of the EU expenditure since 1994.

${ }^{27}$ The European Commission's staff rules are one of the things outsiders find frustrating. These entitle EU foreign service staff 'to 83 days or almost 17 weeks holiday a year ... some posts in third countries are effectively half-time posts for which a full salary is paid' (B. Waterfield, '17 weeks holiday a year for Ashton's EU bureaucrats', The Telegraph, 27 March 2012).

${ }^{28}$ The Sunday Times journalists, posing as lobbyists, tried to verify rumours about corruption at the European Parliament. They contacted about 60 MPs. Three of them were prepared to offer their 'services' (to push specific amendments) in exchange for money. They were personalities such as the former Austrian interior minister (Ernst Strasser), former Romanian deputy prime minister (Adrian Severin) and the former Slovenian foreign minister (Zoran Thaler) (Editorial, 'European Parliament must end this scandal', The Sunday Times, 20 March 2011; APF, 'EU parliament probes MEP corruption claims’, 20 March 2011).
} 
continuous enlargements, monetary integration, passport-free travel, common foreign policy and a certain solidarity among its member states - last-minute solidarity, but still comradeship. Solidarity and possible breaches of solidarity in the EU may sound like familiar music in the former eastern bloc countries. Some of them are openly against such behaviour (Slovakia was resisting the eurozone rescue of Greece). The grounds for resistance are that statements and pressure against a 'breach of solidarity' were earlier issued from communist Moscow, while now the same words are coming from democratic Brussels. Some may regard these solidarityrelated issues as gains, others as burdens. Still, there is a line of countries that wish to join the EU. A problem of unfinished digestion of changes certainly exists, a trend that has grown since the start of the 2000s. Nevertheless, all of these achievements have not been properly explained to the populations of member countries. Integration in Europe is a continuous process, not a settled and final product. Important short-term problems have been overrated, while the longterm EU ability to impact and change things on a large scale has been underestimated. As with Sophism in Ancient Greece and rhetoric in Ancient Rome, public relations in our times ought to be improved by the EU-elite in regard to transparency with the general public.

Economic nationalism may sink or dent the Single European Market, the holy grail of European integration: President Sarkozy's 2009 call to French car makers to repatriate factories from the eastern part of the EU back into France; former British Prime Minister Gordon Brown's call for British jobs for British workers; and buy Spanish campaigns. While there are those in the EU who may accept European integration, even as an unwanted necessity, EU-scepticism is apparent in many central and eastern European EU member countries while elsewhere, there are those who are openly against continued participation in the EU (some in Britain). Those that are about to enter the EU (Croatia) or are striving to join are afraid of what they may find once they get there. Would it be like joining a sumptuous party at five o'clock in the morning when all the food has been eaten, drinks consumed and girls already taken home? What will remain?

Who can slalom through this maze of obstacles and challenges for the benefit of citizens and the EU? It is the European elite. It ought to show vision and leadership. However, the elite made the tactical error of not doing that in the clear way. The elite have often explained economic reforms in terms of belt-tightening policy aimed at increasing the competitiveness of outputs in relation to producers in Asia. EU enlargements may be portrayed as financial burdens and threats to jobs, rather than opportunities. A potentially superior (but harder) path may be to reform member country economies with a vision of long-term economic growth. Investment in policy objectives, especially in education, pays heavily over the long term. The elite ought to articulate this to the public more forcefully to dispel ambivalence and pessimism. No national elite has driven this home in quite the right way, but some of them have got it more wrong than others.

When EU integration was seen as a boring technical matter, the elite could handle it away from the man in the street. Voters were providing neither energy nor breaks. When it came 
to 'bite' them - at the time of eastern enlargement and dislocation of factories to the east or during the introduction of the euro and the subsequent crises - people became much more concerned about the EU. The current problems will force the EU to recalibrate its ambitions. Budget debate is one of the strong litmus tests of solidarity within the EU, as well as a test of its vision of the future. It also exhibits internal EU struggle related to the unfinished business of adjustment to the reality of eastern enlargement.

European integration is a very unselfish project. All the same, times are rather selfish because of low growth and austerity measures. Negotiations about the new Financial Perspective (2014 2020) have revealed differences over the EU budget. Britain and some other countries would like to reduce the current budget, while Poland and other poorer countries would like to enlarge it. European integration is not about the budgetary transfers, but these transfers are a licked finger for what types of solidarity winds are blowing.

The EU is not known for speed in its decision making. The reason is that complicated coalitions arrive at careful compromises (this was until Germany took the EU steering wheel in 2011). The EU is plagued with laws that are costly to enforce. Hence, implementation can sometimes be quite poor. Various existing opt-outs from the acquis communautaire undermine common actions as partner counties in the EU do not all share common values. The EU is therefore a multi-speed organisation. If the development of the EU towards a less structured and a clear multi-speed entity is inevitable or preferred, it ought to be spelt out clearly. The EU may also turn into a multi-directional entity (Britain, eurozone, non-eurozone, southern countries, etc.).

In spite of certain political road bumps the EU operated reasonably well from the advent of the Maastricht Treaty (1992) until the start of the global financial crises (2007 2009). Those 'bumps' were covered by a general economic prosperity. However, the first serious crises revealed deep problems which turned into serious nationalistic political clashes (GermanyGreece; Finland-Greece). The EU has the same legal structure as before the crises (the Lisbon Treaty of 2007 turned out to be a pre-crises treaty for the post-crises EU) but it no longer operates in the same way.

The EU elite thought the financial crisis, especially the eurozone crises, to be a serious but 'technical' affair that could be solved within the existing EU structure. Deals were made, issues were patched-up (at least temporarily), but the crises did not recede. Is the current EU structure sufficient to provide a framework to solve such problems? The EU was created to contain wars in Europe and to keep in check nationalism that provoked devastating military conflicts. Is the new wave of nationalism a temporary anomaly in the European integration process? Or, is it something more permanent? What will be the evolution of the EU? Is its survival at stake?

Pan-EU solutions to various challenges may suffer damage from greater nationalism and a lack of solidarity based on divergences in economic and other forces. The 2010 eurozone crises revealed a serious divide between the core and the (southern) fringe countries. The political will to fix that was not in abundant supply. Still, solidarity prevailed at the very end as the 
consequences of failure could be immeasurable. This type of situation in which solutions are found can be succinctly explained in the words of Jean Monnet: 'People are ready to change when they understand there is no alternative. ${ }^{29}$

Pessimists would argue that the EU was struggling to avoid economic and political decline during the first decade of the $21^{\text {st }}$ century, especially in light of the enthusiastic Lisbon 2000 declaration of intent to make the EU 'the most competitive and dynamic knowledge-based economy in the world capable of sustainable economic growth with more and better jobs and greater social cohesion' by $2010 .^{30}$ This failed. Integration enthusiasts would retort that in the light of serious difficulties, the EU enlarged twice, the eurozone was saved and enlarged, and that states and companies throughout the world respect the EU. The integration enthusiasts would argue that Europe is continuously built step by step. Eurosceptics would retort that the EU is slicing national sovereignty treaty by treaty.

The strategic vision of the EU's future was announced in 2010 under the name 'Europe 2020'. This new, grand strategy, revealed in the midst of the worst economic crises for decades, puts innovation and green growth at the forefront. The new agenda for the decade is a replacement of the previous ill-fated Lisbon strategy for 2000 2010. The Lisbon Agenda failed because, among other issues, governments were not too keen on the process, monitoring was too loose and there were no sanctions for member states that failed to implement the policy. By making innovation and green growth, i.e., the leitmotifs of the new agenda for 2011 2020, the EU intends to create a smarter and greener economy in which resources are going to be better used, prosperity would be based on innovation and the social market economy would be sustainable, while the key input in all this would be new knowledge. 'Europe 2020' sets five ambitious objectives: employment, innovation (investment in R\&D), education, social inclusion and climate/energy. Each EU member country is expected to adopt its own national targets in each of these areas so that they may be reached by 2020. Instead of sanctions, a proposal has been made by van Rompuy that there be rewards: countries that meet targets ought to get extra EU funding.

The EU may need to spend more time in the future looking beyond the administrative process and it must pay more attention to policy. It has the potential to protect and improve the wellbeing of Europeans through the rule of law, democracy, social solidarity, market economy and its excellent tradition in education and the creation of ideas. People themselves ought to be protected in the EU, not each particular job. Therefore, a system of life-long training is necessary.

What the EU needs is economic growth through gains in productivity. Neither monetary nor fiscal policy can provide that on their own. It can be done with the help of hard structural reforms, which have been avoided. These include reforms in the areas of education, pensions,

\footnotetext{
${ }^{29}$ J. Coman, 'Eurozone crisis: European Union prepares for the great leap forward', The Observer, 20 November 2011.

${ }^{30}$ European Council, Lisbon, Presidency Conclusions, 23-24 March 2000, §5.
} 
services, and investment in innovation. Jean-Claude Juncker, long-term Prime Minister of Luxembourg and senior integrator of Europe, said: "We all know what to do, we just don't know how to get re-elected after we've done it." ${ }^{, 31}$ The frequent issue is not what should be in the treaty or laws, but rather what can be ratified.

Europe adapted very well to the rise and dominance of the US. Europe has the energy, resources and ideas to adapt to the Asian challenge and many others too. The EU may continue to lead the world in issues related to energy-saving and the environment. The EU's final economic successes and its other achievements need not be compared to the US or Asia, but rather to the current and future needs of the EU and its citizens. Grave eurozone crises from 2010 onwards exposed national problems and priorities, but the solutions were common. In the search for a solution, the EU went beyond the Treaty of Lisbon. Some argue that more 'Europe' and more of integration is the solution for problems in the future. Others would say that in the future the EU may need to evolve into a less ordered organisation that is more multispeed and multi-directional than is the case now (eurozone and non-eurozone countries are a clear example, the Schengen deal is another).

Germany wants to re-wire the EU according to its preferences, interests and needs. ${ }^{32}$ The opportunity to do so has arrived and the tools are a cheque book and diplomacy. These constitute a more sophisticated vehicle for reaching that German end than the use of panzer divisions, as was the case over the past couple of centuries. If Germany reshapes the EU, then it will be careful not to create strong competitors (France, Italy or Britain) which may turn into geopolitical rivals. This means that Germany may 'abandon' countries such as Greece, Portugal, Ireland, Bulgaria, Latvia and several other minnows with relative 'ease'. Possible German enthusiasm and potential success for an EU in this shape and form will be tested over time in other EU countries. It is therefore necessary to keep the following observation on the 'political radar screen': 'the prophecy attributed to a French official from 30 years ago may prove uncannily accurate. "France will be European as long as Europe is French. When that ceases to apply, France will dispense with Europe",. ${ }^{33}$ Russia is an alternative partner to Germany.

The eurozone and its currency, the euro, is a great federalist project. No single currency has circulated so widely in Europe since the Roman Empire. The eurozone and the euro were the shining crown jewels in the EU integration process, as they came about in a voluntary way during a time of peace. Paradoxically, they are its weakest links. The monetary union succeeded, but the economic union that brings long-term prosperity and growth is yet to arrive. Compared to the preceding situation, a monetary union replaces currency exchange risk with

\footnotetext{
${ }^{31}$ W. Münchau, 'The Dutch are leading the popular rebellion', Financial Times, 27 November 2006.

${ }^{32}$ German Finance Minister Wolfgang Schäuble argued that a new EU treaty is needed to solve the debt crises. The Chancellor, Angela Merkel, said, "I will push for necessary treaty changes...Europe must learn the right lessons for the future" (EurActiv, 'Germany's Schäuble calls for new EU treaty', 2 September 2011).

${ }^{33}$ The Economist Intelligence Unit, 'Twenty questions on the future of Europe', June 2005, p. 13.
} 
a credit risk. If national governments spend excessively, the depreciation of the exchange rate of the national currency is replaced by increases in the rate of interest on national government bonds.

Many would point fingers at the 'prodigal' Greeks as the cause of their financial troubles. To an extent, reckless expenditure and Greece's flouting of the eurozone's rules were the reasons for economic disaster. However, the Greeks are not the only culprits in this catastrophic situation. Bankers in Europe were recklessly lending to Greece in the full knowledge that the loans would not be repaid. In fact, sales to Greece were strongly encouraged. Hence the blame ought to be shared. Here are just a few illuminating examples that have surfaced. Ferrostaal, the German arms producer, was fined ( $€ 149$ million) in 2011 for giving $€ 62$ million in bribes to the Greeks for their purchase of (faulty) submarines. ${ }^{34}$ In March 2012, the Greek government reached an out-of-court settlement with German company Siemens relating to bribes. Siemens would pay a fine of $€ 170$ million for bribes to Greek state employees and ministers for the procurement of equipment. ${ }^{35}$

Germany has an unprecedented peaceful opportunity to shape Europe according to its liking. It is seizing this unique opportunity, the first in EU history. Hyperactive France is trying to influence that course of action as much as it politically and economically can. The FrancoGerman duo is attempting to come up with new ideas and solutions for the shape and pace of European integration. Other actors are playing second fiddle or are standing by and waiting to implement imposed results. Still, it is Germany that calls the tune and puts a price on its involvement in integration in Europe. To put it bluntly: integration may and should continue, but on German terms as is obvious from the present unfinished eurozone crisis.

There are weighty and fundamental questions: How much is this type of European integration process in line with the original European integration ideals? Was European integration supposed to take care of European or national (especially one nation) interests?

Who is actually in charge of the EU? Who is compering on the EU microphone? Is it European Council President Herman van Rompuy, European Commission President Jose Manuel Barroso, the rotating six-month EU presidency national president/prime minister or the speaker of the European Parliament? There are too many presidents. And there is also EU Foreign Minister Catherine Ashton as the EU foreign policy 'Kaiser'. In spite of what may be said in public, a fragmented or paralysed Europe has almost always been in US interests: it could be more easily manipulated. Henry Kissinger's famous remark, 'Who do I call if I want

\footnotetext{
${ }^{34}$ 'Ferrostaal shareholders approve EUR149 million fine in bribery case', The Wall Street Journal, 14 October 2011; Pitelis (2012, p. 8).

The EU countries sold Greece over $€ 1$ billion of arms during the first bailout deal in 2010 . France was the biggest seller, but the proausterity advocates (Germany and the Netherlands) were also active. 'An aide to the then Greek leader, George Papandreou, who asked to remain anonymous, told the news agency: 'No one is saying 'Buy our warships or we won't bail you out.' But the clear implication is that they will be more supportive if we do"' (A. Rettman, 'EU figures show crisis-busting arms sales to Greece', EU observer, 7 March 2012).

${ }^{35}$ K. Hope, 'Siemens to pay $€ 170 \mathrm{~m}$ to Greece over alleged bribery of officials', Financial Times, 9 March 2012.
} 
to speak to Europe?' is getting an answer. Call the German chancellor.

Eurosceptics are receiving fuel for their ideas, not as a product of their campaigns but rather because of the super-ambitious elitist projects which have been tested against markets (monetary union without a high degree of fiscal and political integration) and political realities (a flood of refugees and protests against austerity measures). They argue that the 'European dream' is falling apart. The integration model based on the Treaty of Rome (1957) and its subsequent revisions now looks more like the nation-state integration model based on the Treaty of Westphalia (1648). This is exactly what European integration was against. The enlarged EU of 27 countries has strong intergovernmental features, rather than its original common union-type dimensions. Therefore, the careful navigation of European integration through rough waters is necessary.

The eurozone countries are informally supposed to be leading EU integration (first division). Other EU countries are tacitly taken to be in the second EU division. The EU avant-garde is presumed to be the economic engine of the EU and the end point for other EU countries. Table 1 presents the growth rates in the countries belonging to the two EU 'divisions'. The first division shows little or no growth, while the second division fairs much better according to this important economic indicator. Should the two divisions perhaps change division 'labels'?

Table 1. Real GDP Growth rates in the EU and

Selected External Countries : 2005 2013

(\% change on previous year)

\begin{tabular}{|l|c|c|c|c|c|c|c|c|}
\hline \multicolumn{1}{|c|}{ Country } & $\mathbf{2 0 0 6}$ & $\mathbf{2 0 0 7}$ & $\mathbf{2 0 0 8}$ & $\mathbf{2 0 0 9}$ & $\mathbf{2 0 1 0}$ & $\mathbf{2 0 1 1}$ & $\mathbf{2 0 1 2}^{\mathbf{f}}$ & $\mathbf{2 0 1 3}^{\mathbf{f}}$ \\
\hline EU (27 countries) & 3.3 & 3.2 & 0.3 & -4.3 & 2.1 & 1.5 & 0.0 & 1.3 \\
\hline Euro area (17 countries) & 3.2 & 3.0 & 0.4 & -4.4 & 2.0 & 1.4 & -0.3 & 1.0 \\
\hline \multicolumn{1}{|c}{ EU First Division } & & & & & & & & \\
\hline Austria & 3.7 & 3.7 & 1.4 & -3.8 & 2.1 & 2.7 & 0.8 & 1.7 \\
\hline Belgium & 2.7 & 2.9 & 1.0 & -2.8 & 2.4 & 1.8 & 0.0 & 1.2 \\
\hline Cyprus & 4.1 & 5.1 & 3.6 & -1.9 & 1.3 & 0.5 & -0.8 & 0.3 \\
\hline Estonia & 10.1 & 7.5 & -4.2 & -14.1 & 3.3 & 8.3 & 1.6 & 3.8 \\
\hline Finland & 4.4 & 5.3 & 0.3 & -8.5 & 3.3 & 2.7 & 0.8 & 1.6 \\
\hline France & 2.5 & 2.3 & -0.1 & -3.1 & 1.7 & 1.7 & 0.5 & 1.3 \\
\hline Germany & 3.7 & 3.3 & 1.1 & -5.1 & 4.2 & 3.0 & 0.7 & 1.7 \\
\hline Greece & $5.5^{\mathrm{p}}$ & $3.5^{\mathrm{p}}$ & $-0.2^{\mathrm{p}}$ & $-3.1^{\mathrm{p}}$ & $-4.9^{\mathrm{p}}$ & $-7.1^{\mathrm{p}}$ & -4.7 & 0.0 \\
\hline Ireland & 5.4 & 5.4 & -2.1 & -5.5 & -0.8 & 1.4 & 0.5 & 1.9 \\
\hline Italy & 2.2 & 1.7 & -1.2 & -5.5 & 1.8 & 0.4 & -1.4 & 0.4 \\
\hline
\end{tabular}




\begin{tabular}{|l|c|c|c|c|c|c|c|c|}
\hline Luxembourg & 4.9 & 6.6 & -0.8 & -4.1 & 3.0 & 1.7 & 1.1 & 2.1 \\
\hline Malta & 3.2 & 4.6 & 4.0 & -2.4 & 3.4 & 1.9 & 1.2 & 1.9 \\
\hline Netherlands & 3.4 & 3.9 & 1.8 & -3.7 & 1.6 & 1.0 & -0.9 & 0.7 \\
\hline Portugal & 1.4 & 2.4 & 0.0 & -2.9 & 1.4 & -1.7 & -3.3 & 0.3 \\
\hline Slovakia & 8.3 & 10.5 & 5.8 & -4.9 & 4.4 & 3.2 & 1.8 & 2.9 \\
\hline Slovenia & 5.8 & 7.0 & 3.4 & -7.8 & 1.2 & 0.6 & -1.4 & 0.7 \\
\hline Spain & 4.1 & 3.5 & 0.9 & -3.7 & -0.3 & 0.4 & -1.8 & -0.3 \\
\hline \multicolumn{1}{|c}{ Second EU Division } & & & & & & & & \\
\hline Bulgaria & 6.5 & 6.4 & 6.2 & -5.5 & 0.4 & 1.7 & 0.5 & 1.9 \\
\hline Czech Republic & 7.0 & 5.7 & 3.1 & -4.5 & 2.5 & 1.9 & 0.0 & 1.5 \\
\hline Denmark & 3.4 & 1.6 & -0.8 & -5.8 & 1.3 & 0.8 & 1.1 & 1.4 \\
\hline Hungary & 3.9 & 0.1 & 0.9 & -6.8 & 1.3 & 1.6 & -0.3 & 1.0 \\
\hline Latvia & $11.2^{\mathrm{b}}$ & $9.6^{\mathrm{b}}$ & $-3.3^{\mathrm{b}}$ & $-17.7^{\mathrm{b}}$ & $-0.9^{\mathrm{b}}$ & $5.5^{\mathrm{b}}$ & 2.2 & 3.6 \\
\hline Lithuania & 7.8 & 9.8 & 2.9 & -14.8 & 1.5 & 5.9 & 2.4 & 3.5 \\
\hline Poland & 6.2 & 6.8 & 5.1 & 1.6 & 3.9 & 4.3 & 2.7 & 2.6 \\
\hline Romania & 7.9 & 6.3 & 7.3 & -6.6 & -1.6 & 2.5 & 1.4 & 2.9 \\
\hline Sweden & 4.3 & 3.3 & -0.6 & -0.5 & 6.6 & 3.9 & 0.3 & 2.1 \\
\hline United Kingdom & 2.6 & 3.6 & -1.0 & -4.0 & 1.8 & 0.9 & 0.5 & 1.7 \\
\hline \multicolumn{1}{|c|}{ Memorandum Countries } & & & & & & & & \\
\hline Norway & 2.5 & 2.7 & 0.0 & -1.7 & 0.7 & 1.4 & 1.7 & 2.0 \\
\hline Switzerland & 1.7 & 2.2 & -1.0 & -5.5 & 4.5 & -0.8 & 1.9 & 1.7 \\
\hline United States & & & -1.9 & 3.0 & 1.9 & 0.9 & 1.7 \\
\hline Japan & & & -3.1 & 2.4 & 1.8 & 2.0 & 2.1 \\
\hline & 2.9 & & & & \\
\hline
\end{tabular}

(Note) $f=$ forecast $b=$ break in series $p=$ provisional

(Source) Eurostat

Last update: 11 . October 2012

Date of extraction: 12 October 2012

Hyperlink to the table: http://epp.eurostat.ec.europa.eu/tgm/table.

do $?$ tab $=$ table $\&$ init $=1 \&$ plugin $=1 \&$ language $=$ en $\&$ pcode $=$ tec 00115

The old EU order needs to be reconsidered. ${ }^{36}$ Potential scenarios for the new EU era vary from bad to better, but not splendid for a decade or more to come:

\footnotetext{
${ }^{36}$ W. Laqueur, 'The slow death of Europe', The National Interest, 16 August 2011.
} 


\section{A. Bad}

Pressure from the financial market may force the EU to make radical and deep changes which would provoke a slow-motion political train crash. The EU may fall apart or get rid of its weaker members. The 'ousted' member countries may need to receive therapy in the form of political and economic 'steroids'. Once they improve, they may be promoted again to the 'premier league' of EU countries, if it still exists. This scenario is the toughest possible as it may be costlier for a country to step out of the EU than to remain inside it. The policies (harsh austerity) that are supposed to resolve the eurozone crisis cause more damage than the problems they are supposed to solve.

The new German template (strict rules and punishments) for the operation of the EU may provoke perpetual austerity and no growth. However, growth may be the best remedy for the EU. How does this square with other countries' visions of the EU? Spain, for instance. The austerity rules may easily provoke violence and extremism as one country imposes its rules on others. Suspicions are paramount - the thrifty northern Protestants vs. the prodigal southern Catholics and Orthodox; Britain vs. the Continent; everyone vs. the Germans. It is amazing how half a century of European integration has not managed to dissipate deep-seated mistrust and cultural conflicts. Jovanović (2012, p. 77) wrote:

During the Great Depression, Heinrich Brüning, the German Chancellor (1930-32), thought that a strong currency and a balanced budget were the ways out of crisis. Cruel austerity measures such as cuts in wages, pensions and social benefits followed. Over the years crises deepened. This led to what the reader of this article knows. ${ }^{37}$ Once the financial and the existential storm is over and new EU architecture is in place based on the tough German template, a number of EU countries may not like or enjoy the EU that they live in. Many of them may find themselves in the slow-lane of European integration. The EU will not be the same again. It is turning into a multi-speed and multi-directional EU.

If the eurozone is broken up, for instance, the EU may return to the situation where it was in 1985. Many would argue that this may not be a bad result at all compared to the possible dissolution of the EU. Martin Schultz, President of the European Parliament, said in 2012 that 'the collapse of the European Union is a realistic scenario'. ${ }^{38}$ In this scenario, the EU's countries would worry more about keeping the existing EU order and institutions, than holding Britain in the EU project (despite the fact that the departure of such a big fish would be a blow to global EU prestige).

\footnotetext{
${ }^{37}$ The stringent euro template acts as the gold standard. If the template survives without changes (easing), the fear is that the economic costs may be calculated not in terms of money, but rather in terms of dead bodies.

${ }^{38}$ Stratfor, 'Nationalism, populism and the collapse of the EU', 27 April 2012.
} 


\section{B. Improvement}

The EU has weathered several serious and deep crises, approximately one a decade. These include the French 'empty chair' (1965); de Gaulle vetoes regarding British EU entry; Britain wanting its money back from the EU (1979); the rift between France and Germany concerning the disintegration of Yugoslavia (1991); the resignation of the European Commission (1999) after allegations of corruption in top positions; the 2005 referendums in France and the Netherlands which rejected the European Constitution; the eurozone crisis that started in 2009; the attack on Libya and an inflow of immigrants (2011). Scepticism about European integration was spreading at these times. Ultimately, each crisis ended rather well for European integration. This may be the case again, even though earlier crises were far from the fortitude of the eurozone-type crises and which still rock the EU towards the brink of disaster.

Many countries have experienced deep economic crises from which they recovered and emerged stronger. Just remember the US and the Great Depression 1929 1932; France after being defeated by Germany (1870 1871); Germany and Japan after the two World Wars; or Russia after the end of the Soviet Union in 1991. It took those countries one or two decades to recover. This is expected to also happen with the EU. During the eurozone crisis, especially in Italy, the President of the European Commission, Barroso, called on the EU to 'unite or face irrelevance'. ${ }^{39}$ So, the EU may go for a fiscal, banking and political union, while countries would give up more of their sovereignty to the EU's institutions. This will be a challenging and most difficult task for many EU countries.

The EU needs to gain renewed vigour and dispel doubts about its future. ${ }^{40}$ There are various glues which successfully hold big countries and unions together. In the US, it is the Constitution. In China, it is the Communist Party and the state apparatus. The EU must offer now and in the future more than a vague promise of economic prosperity.

\footnotetext{
${ }^{39}$ L. Elliott, H. Stewart and J. Hopper, 'European debt crisis spiralling out of control’, The Guardian, 9 November 2011.

${ }^{40}$ Stratfor puts this in the following way: 'Old elites find themselves targets of the anger, mainly for bailing out their supposed banking friends with taxpayer money. The problems are deeper than that. The European Union without the Cold War or a recent memory of the devastation of the World War II has become nothing more than an economic project, which loses its rationale with the prolonged economic crisis. Supranational elites jetting from Paris to Luxembourg to Frankfurt are finding it difficult to rationalize the continuation of the project, and therefore their elite status, since the economic situation has deteriorated' (Stratfor, 'The Relevance - and Irrelevance of the Strauss-Kahn Arrest', 17 May 2011).

Peter Spiegel, the Financial Times' Brussels chief argued that 'we may be witnessing a generational change in European political dynamics. Traditional left-right divisions have narrowed. No mainstream social democrat now advocates centralised economic planning, just as no conservative candidate seriously questions the underpinning of the welfare state.

In its place, we are seeing a new division, between globalisers and localisers. The urban elites on both the left (intellectuals, liberal internationalists) and the right (free traders, global business leaders) face a challenge to their postwar consensus from a new group of revanchists.

This political force also comes from both the left (trade unionists, working-class whites) and the right (rural nationalists, far-right xenophobes). More importantly, it may spell a new, unprecedented challenge to the European project' (P. Spiegel, 'European integration is unravelling', Financial Times, 30 May 2011).
} 


\section{Muddling through}

Most politicians excel in this type of buying time in the hope of a miracle (economic growth fairy). There may be some reforms and a bit of business as usual. This would be a compromise between Teutonic clarity in ideas and the tumultuous European reality. Hard decisions concerning reforms (eurozone for instance) may be postponed for the future.

The European marriage may be gloomy and unhappy, but it may endure. This scenario may be the most likely and may lead into a decade of EU 'decline' after the first decade of the $21^{\text {st }}$ century, which might have been 'lost' for the EU. Political hopes and wishes exist, but the expected and promised perpetual prosperity is fading away. It would be difficult to dissipate widespread scepticism and to restore confidence in the European integration project without tangible economic growth and new jobs. This is a challenging task as population ages and new highly productive technologies (investment) do not offer hints that growth may be forthcoming. Without growth, it may be easy for many to ask: What the EU is for? The danger is that an extension of the political agony (need for deeper reform now) will increase the cost of reform in the future. The EU may not have the tools necessary to encounter the next crisis. It may remain a large, reasonably important but a rather joyless, conflict-prone and unhappy family of states based on rules and penalties, discipline and punishments. As such it may not exercise its full clout in international affairs and provide the model for others on how to deal with subjects such as protection of the environment, green energy or democracy (e.g., as it did to the Arab world following the Arab Spring in 2011).

\section{Europe and Optimism of Ostriches}

What is the story that the EU would like to tell the citizens of the future? The past stories are known: peace, economic prosperity, the single market, monetary union and enlargement. Is the new story a green economy and growth? Or perhaps the EU integration currency is not a part of this story but instead a Venice-type lifestyle that many would like to enjoy. Unfortunately, as in the Venetian Republic (697 1797) and modern-day Venice, only a relatively small and dwindling number of persons are able to afford such an existence, just like in the late Soviet Union. The EU's success increasingly depends on the overhaul of the economic system and the integration of immigrants. The Venetian Republic failed to live up to this tall order of things, but still lived well for centuries. ${ }^{41}$ The EU ought to keep this important lesson in mind.

Regulation and more regulation is the EU template. The Lisbon Treaty is a dull and mysterious document. Instead of a single understandable document, it contains amendments to

\footnotetext{
${ }^{41}$ The Venetian Republic also established a strong republican-type of government in a Europe full of monarchies.
} 
the existing treaties. This is because (Curzon, 2011, p. 9):

'True agreement' on the nature and long-term aims of the European Union does not exist, which is why most governments have avoided submitting the Lisbon Treaty to public referenda, preferring to pass it off as a mere 'technical' amendment to existing treaties.

The Lisbon Treaty is incomprehensible to people with average intelligence and education. It is, however, a paradise for lawyers, consultants and masochists. It was deliberately made such in order to rework and recycle the draft EU constitutional treaty (rejected in a referendum both by France and the Netherlands in 2005).

The EU's regulation tentacles cover, among many issues, the welfare of animals. For instance, pigs must have "permanent access to manipulable material' ${ }^{42}$ to avoid boredom. The British Department for Environment, Food and Rural Affairs defined that as balls. 'Farmers may also need to change the balls so the pigs don't get tired with the same ones. Different colour ones will do. ... But farmers should be careful about scoffing at the idea: they could be fined up to $£ 1,000$ or jailed for three months if they fail to amuse their stock. ... Mark White, past president of the Pig Veterinary Society, said: "Pigs have a habit of chewing each other and they do it in all environments and especially go for pigs' tails and ears." ${ }^{43}$ Some argue in favour of this type of animal welfare, while others deem it absurd.

The EU was built, kept and flourished on voluntary integration, solidarity, perception of a common future and political handling of diversity. An emerging new EU (post 2007 2009 financial crisis) is turning more towards an intergovernmental EU, not the one that is based on the 'community method' of organisation and leadership in which there is a constant primacy of European over national interest. An emerging new EU is turning into a group of countries centred around punitive rules based on the implicit or explicit German template. Is Germany alone in the EU cockpit? Political handling of diversity is being replaced by a straitjacket. Just how appealing this new fashion will be in the future is another matter. The eurozone rescue deal to control and approve how countries tax and spend shows that the national sovereignty of many countries is fading away, bit by bit. If voters cannot vote on the national budget (taxes and expenditure), what are they voting for? Apart from the loss of sovereignty, employment prospects for the younger generation may be wrecked, while this all provides energy to extreme political movements and fuels their ideas.

If the eurozone falls apart, all bets regarding the EU are off. If the eurozone survives the crisis, the nature of the EU may change beyond recognition: there would be fiscal, banking and political unions. There would likely be an EU commissioner who would have authority over national budgets. An appointed EU financial 'Kaiser' would be able to control and overrule what the people democratically voted for through their governments. To the federalists, this

\footnotetext{
${ }^{42}$ Council Directive 2008/120/EC of 18 December 2008 laying down minimum standards for the protection of pigs (Article 3).

${ }^{43}$ V. Elliott, 'Why all pigs are having a ball', The Times, 29 January 2003.
} 
development may be the goal of integration; to others this sounds frightening.

The fundamental idea behind European integration was the prevention of wars and perpetual prosperity as a means of achieving peace. The legitimacy of the basic idea may be put into question if these goals are not honoured. If either wars break out or there is a heavy decline in the general standard of living in the EU (or some parts of it), the legitimacy of the EU may be in jeopardy. If the 'dark masters' of the European integration art (the elite) defend the EU project to safeguard their own position, influence and privileges, then the general public may doubt the need for and effectiveness of the EU and turn nationalistic. The elite does not pay the price for its illusions and failures, but rather it's the general public which loses jobs, salaries, careers, pensions, student grants, health care benefits and homes. The legitimacy of the European integration project is not lost. However, it is facing its toughest test ever because of the eurozone crises. To lose national sovereignty for perpetual prosperity may sometimes be acceptable. To lose it in order to save big (foreign) banks is a much tougher political currency to sell to the public.

Economic integration and the loss of sovereignty were palatable to European countries in the era when there was a vision and expectation of economic prosperity. At a time of crisis, austerity, public protests and a dim hope of economic prosperity, EU countries are reevaluating their national positions on the EU and doubt if giving up more of their sovereignty is to their advantage. While some countries (Britain) may be on the way out of the EU, other EU members look on with sympathy (or pity) as nations from the Balkans make clear their desire to join the group.

Public opinion in EU countries holds certain reservations about the EU. Incidentally, the EU is often highly praised in the countries that would like to join the EU or model their integration project on the EU example. Doubts about the EU may be transitory and shallow. Many have forgotten what Europe was like when it was divided. Strong fences rarely make good neighbours. Cooperation and the lifting of barriers had commendable results in Europe. Europe has never been more democratic, freer and more united (at least until the eurozone crisis) on voluntary bases. Only someone without reason would wish for Europe to return to the horrors that produced clashing fiefdoms throughout the $19^{\text {th }}$ century and the first half of the $20^{\text {th }}$ century. The Nazis were defeated, the dictators were ousted and the communist Soviet Union fell apart. Many things that European integration brought to its citizens are taken for granted: peace, studies abroad, free travel and work in another country and no customs checks. Many young people do not even recall seeing or using any money other than the euro. All of this is the European integration currency that ought to be preserved if the alternative includes the possibility of a return to the conflicts and wars that punctuated the past. 


\section{Lessons for Southeast Asia}

There is a dynamic and changing world outside of Europe, especially in Asia. After two centuries the centre of global gravity in human affairs and economic energy is moving strongly eastwards, away from Europe and North America. Hence, Europe needs to be ready for a more modest global role in the future, even though its principal international rivals have problems of their own. Nothing short of a catastrophe would prevent Asia, especially China, from continuing to develop and becoming much more prosperous and important on a global scale. While the EU discusses its forms of internal organisation and follows a slow and heavy institutional process, China (even Turkey) exercises a pragmatic, flexible and a rather simple approach to direct relations and securing resources and markets in Africa.

The European model of integration is context, region and time specific. The initial conditions for integration differ significantly between post-Second World War Europe and Asia today. Therefore, little can be transplanted from Europe to elsewhere. Southeast Asia ought to find its own integration path and learn, as much as possible, from the experience of others. Here are several ideas:

\section{A. Leadership}

European countries are small in comparison with many in Southeast Asia such as China, Indonesia or Japan. European integration started in unique post-Second World War circumstances when there was an enthusiasm and need for a profound change. Germany was defeated so France was able to take the lead and start to shape Western Europe according to its own template, of course supported by the Marshall Fund from the US. The US supported European integration because of its fear of the Soviet Union. The situation in Southeast Asia is different. Baldwin (2012, p. 25) stated:

Europe started its integration sequences when the demand for regional institutions was unprecedentedly high and resistance to them was unprecedentedly low. Asia starts when the demand for regional institutions is modest and resistance is high.

Who will lead integration in Southeast Asia? The region's countries are so diverse in all dimensions and respects. China, Japan, South Korea or the Association of Southeast Asian Nations (ASEAN) may compete to 'take the microphone' for the region. Many countries have a lot of unsettled border problems which create tensions. These problems can be overcome, 
as was the case between China and Russia. ${ }^{44}$ Good neighbours may be created and maintained. If tensions between countries continue, this may work in favour of the US. It is easier for the Americans to handle disunited and quarrelsome states than to face a united Asian economic and political bloc of countries (especially if it is led by China). In any case, one may expect endless manoeuvring among the principal countries on the region. Hence, the leadership and institutional structure in Southeast Asia may be light and linger between the 'doughnut and the hole'.

\section{B. Institutions}

The EU has a Byzantine supranational decision-making process which is understood only by the specialists. It is far removed from the man on the street. This process may hide the real substance: decisions are taken by the elite, which use various EU institutions to provide a democratic sugar-coating on the process. Asian countries are reluctant to pass on parts of national sovereignty to supranational institutions. These countries pay more attention to pragmatic solutions and outcomes than to quasi-democratic, slow and heavy international procedures.

A possible light institutional structure in Asia ought to assist in the coordination, mutual recognition, even harmonisation of standards that would support trade, investment and supply chains and networks made possible by the technological fragmentation of the production process. Import substitution became unnecessary and unprofitable in circumstances when firms are able to profit from the coordinated large-scale production of components in various places. The problem is which standards need to prevail? Who will call the tune in these matters: China, Japan, South Korea or should those standards come from Europe or the US? Should there be common standards? These are important issues which may be solved by discrete market-led and government-supported forces.

\section{Trade}

Competition and trade relations in the EU are strictly regulated, guided, monitored and sanctioned by the public authorities. Asia has a flexible bottom-up approach driven by markets. Trade and foreign investment exploded, while flexible international production, supply chains and networks expanded. This was based on and supported by pragmatic and discrete trade facilitation measures of unknown individual impact (customs procedures, quarantine process, alignment of standards) in the absence of regional rules and institutions (exception is the

\footnotetext{
${ }^{44}$ A long-term border problem provoked a seven-month long military conflict on the Ussuri River in 1969. The problem was solved by diplomatic means in 2008. Hence, this may serve as an example for the solution of other border problems in the region.
} 
ASEAN). The overall objective is a reduction in trade and transaction costs. There is evidence that trade costs fell in East Asia faster than the global average in the period 1990 2007 (Pomfret, 2011, p. 383). In this light, pragmatic bottom-up economic integration in Asia does not fit into the standard textbook classification of integration agreements. In reality Southeast Asia is not creating a free trade area or a customs union or a common market, but rather a region for trade and investment-friendly business with soft internal/external frontiers and a discrete institutional structure.

Measured by the volume of trade and foreign direct investment, Southeast Asia is already advanced in integration - discrete integration. The coordination of various trade and investment-friendly measures may be supported and eased by a (light) regional institution. Possible common rules of origin ought to be simple to understand, unrestrictive and easy to apply (compliance and administrative costs need to be minimal). Regional cumulation of valueadded and high external value content ought to be the norms. The 'noodle bowl' of rules ought to be eliminated or be as simple as possible in order to avoid market fragmentation. Border crossing needs to be smooth, swift and seamless to support the efficient supply chains and to avoid corruption. This all deals mainly with the production of goods. However, countries in Asia ought to be much more open to trade and investment in services too. In addition, cooperation (rather than rivalry) in the field of energy may also be a promising economic area in Southeast Asia.

\section{Monetary Affairs}

Monetary integration is not necessary for successful economic integration. However, it may be a welcome supporting tool if created and operated properly. In any case, if based on fiat money, ${ }^{45}$ monetary integration needs strong federal institutions and fund transfers (the gold standard, however, operated without any global supervision). Monetary integration in the EU was based on the political compromise and on criteria not known in economic theory. Trouble was inevitable (Jovanović, 2012). The EU is facing years, even a decade of crisis, stagnation, divisions among the EU countries and rifts within the eurozone group, while at the same time Asia moves rapidly ahead. In the absence of federal institutions, fiscal transfers and international labour mobility, spontaneous monetary integration through coordination and mutual support may be an option for Southeast Asia.

The 2000 Chiang Mai Initiative by China, Japan, South Korea and the ASEAN countries to support each other in the case of a crisis in their balances of payments is most helpful. This virtual fund puts $\$ 240$ billion at their disposal. The member countries may count on this

\footnotetext{
${ }^{45}$ Fiat money is a Chinese invention from the $11^{\text {th }}$ century AD. In simple terms, it is a firm and government-sanctioned promise to pay, written on paper. It was brought to Europe by Marco Polo.
} 
amount to service their debt and to maintain stability in the exchange-rate market. The purpose is to reduce the reliance by these countries on the International Monetary Fund as the lender of last resort. As China, Japan and South Korea provide the bulk of the fund's means, the ASEAN countries are the likely beneficiaries. The problem is that the conditions for the disbursement of the resources have not yet been established, while given the size of the economies in question, the resources may not be sufficient in the case of a crisis. Hence, an Asian Monetary Fund is a distant possibility.

\section{E. Enlargement}

The enlargement process in the EU was seen as a step by which the EU values were spread throughout the continent. The creation of new regional groups in Southeast Asia or an enlargement of the existing ones may have two dimensions. The first is genuine integration in order to enlarge and secure markets, benefit from economies of scale, increase stability. The question is if such enlargement would create a border in the middle of the Pacific Ocean. The second dimension may have another slant. If the regional group enlarges - for instance, if Australia joins - would this step create an American Trojan Horse in Southeast Asia that would spoil integration in the region?

The basis for integration in Southeast Asia may remain in a shared interest in relatively spontaneous (bottom up) cooperation in the facilitation of smooth trade and investment, based on a light institutional structure, rather than in defined goals such as strong EU-type common trade, competition, and industrial, agricultural and monetary policies.

\section{Conclusion}

David Hume wrote in his essay 'Of the jealousy of trade' in 1752 a message that is at least as relevant today as it was during his time and even much earlier:

I will venture to assert, that the increase of riches and commerce in any one nation, instead of hurting, commonly promotes the riches and commerce of all its neighbours; and that a state can scarcely carry its trade and industry very far, where all the surrounding states are buried in ignorance, sloth, and barbarism. ... I shall therefore venture to acknowledge, that, not only as a man, but as a British subject, I pray for the flourishing commerce of Germany, Spain, Italy and even France itself. I am at least certain, that Great Britain, and all those nations, would flourish more, did their sovereigns and ministers adopt such enlarged and benevolent sentiments towards each other. ${ }^{46}$

\footnotetext{
${ }^{46}$ http://www.econlib.org/library/LFBooks/Hume/hmMPL29.html\#Part\%20II,\%20Essay\%20VI,\%20OF\%20THE\%20
} 
Countries grow rich and prosperous together, not at each other's expense. Otherwise, if at the end there is only one winner, they will find nobody to talk to. A certain sharing of wealth and prosperity is necessary for growth and progress. While the balance of trade matters to an extent, the mere balance does not show a country's gain or loss from trade. What matters for the gains from trade to materialise is the volume, rather than the mere balance of trade. The larger the volume of trade, the larger the international impact on competition, allocation of resources and welfare.

Received 30 October 2012, Revised 30 November 2012, Accepted 4 December 2012

\section{References}

Baldwin, R. (2012). 'Sequencing Asian regionalism: theory and lessons from Europe', Journal of Economic Integration, pp. 1-32.

Chia, Y. (2010). 'Trade and investment policies and regional economic integration in East Asia', ADBI Working Paper Series No. 210.

Curzon Price, V. (2011). 'Institutional competition in the European Union: causes and consequences of the drive to harmonise', in International Handbook on the Economics of Integration: Competition, Spatial Location of Economic Activity and Financial Issues (ed. M. Jovanović). Cheltenham: Edward Elgar, pp. 3-20.

Eichengreen, B. (2007), ‘The breakup of the euro area', NBER Working Paper 13393.

Hiratsuka, D. (2011). 'East Asia's economic integration and institutional cooperation for further integration', in International Handbook on the Economics of Integration: General Issues and Regional Groups (ed. M. Jovanović). Cheltenham: Edward Elgar, pp. 393-415.

Hiratsuka, D., and Y. Uchida (eds)(2010). Input Trade and Production Networks in East Asia. Cheltenham: Edward Elgar.

Jovanović, M. (2012). 'Is the eurozone rescue strategy tantamount to the rearrangement of the deckchairs on the Titanic?', Journal of Economic Integration, pp. 33-79.

Jovanović, M. (2013). The Economics of European Integration. Cheltenham: Edward Elgar.

Livingston, K. (1987). If Voting Changed Anything, They Would Abolish It. London: Collins.

Messerlin, P. (2001). Measuring the Cost of Protection in Europe. Washington: Institute for International Economics.

Pitelis, C. (2012). 'On PIGS, GAFFs and BRICs: An insider-outsider's perspective on the structural and industrial foundations of the Greek crisis', Judge Business School, University of Cambridge, mimeo.

Pomfret, R. (2011). 'Regional integration in East Asia', in International Handbook on the Economics of Integration: General Issues and Regional Groups (ed. M. Jovanović). Cheltenham: Edward Elgar, pp. 377-392.

Praussello, F. (2011). 'Asymmetric shocks and monetary disintegration: the case of the eurozone', in 
International Handbook on the Economics of Integration: Competition, Spatial Location of Economic Activity and Financial Issues (ed. M. Jovanović). Cheltenham: Edward Elgar, pp. 360-377.

Sidjanski, D. (2011). 'A new era for Europe: the Lisbon Treaty - from Constitution to Lisbon Treaty', in International Handbook on the Economics of Integration: General Issues and Regional Groups (ed. M. Jovanović). Cheltenham: Edward Elgar, pp. 279-300. 